\title{
CHEMICAL, CLINICAL, AND IMMUNOLOGICAL STUDIES ON THE PRODUCTS OF HUMAN PLASMA FRACTIONATION. \\ IX. THE TREATMENT OF SHOCK WITH CONCENTRATED HUMAN SERUM ALBUMIN: A PRELIMINARY REPORT ${ }^{1,2}$
}

\author{
By J. V. WARREN, E. A. STEAD, JR., A. J. MERRILL, AND E. S. BRANNON \\ (From the Medical Service of the Grady Hospital and the Department of Medicine, Emory University \\ School of Medicine, Atlanta, Georgia)
}

(Received for publication February 17, 1944)

We have had the opportunity to treat $6 \mathrm{pa}$ tients in shock with concentrated human serum albumin, prepared from pooled normal human plasma by the method of Cohn and co-workers (1). ${ }^{3} \quad$ Five of these patients had circulatory failure from hemorrhage and the sixth from extensive burns. These observations were made at the beginning of our experience with the technics utilized in the study of shock by Cournand and co-workers (3). At this time, routine determinations of the cardiac output before and after therapy were not being made.

\section{METHODS}

The arterial pressure was recorded from the femoral artery by the method of Hamilton (4). The mean pressure was computed from planimetric measurement of these tracings. The right auricle was catheterized by a method only slightly modified from that reported by Cournand and Ranges (5). Mixed venous blood was obtained from the right auricle and arterial blood from the femoral artery. The oxygen content of these specimens was determined by the method of Van Slyke (6). Oxygen consumption was determined by measurement of the volume and composition of a 2-minute sample of expired air obtained in a Douglas Bag. From these data, the cardiac output was calculated, utilizing the Fick principle. Plasma volume determinations were carried out with the

\footnotetext{
1 The work described in this paper was done under a contract, recommended by the Committee on Medical Research, between the Office of Scientific Research and Development and the Emory University School of Medicine.

2 The products of plasma fractionation employed in this work were developed from blood, collected by the American Red Cross, by the Department of Physical Chemistry, Harvard Medical School, Boston, Massachusetts, under a contract, recommended by the Committee on Medical Research, between the Office of Scientific Research and Development and Harvard University.

3 This study was carried out in order to provide more detailed information on the mechanism of the action of albumin in shock than was possible in the original clinical appraisal (2).
}

use of the blue dye, T-1824, as described by Gregersen, Gibson, and Stead (7), and adapted to the Klett photoelectric colorimeter or the Beckman quartz spectrophotometer. Plasma protein concentration was determined by the specific gravity method of Barbour and Hamilton (8).

\section{RESULTS}

Case 1. A 45-year-old Negro was admitted to Grady Hospital because of stab wounds of the right forearm, forehead, and right flank. He had bled profusely, but there was no evidence of penetration into the peritoneal cavity. He had been drinking whiskey and the blood alcohol concentration was $180 \mathrm{mgm}$. per cent. The tongue was pale, the radial pulse was weak, and the extremities were cool. There was no sweating. The veins of the forearm were visible and appeared full. The venous blood from the antecubital vein was dark. The systolic brachial blood pressure by the auscultatory method was $80 \mathrm{~mm}$. of $\mathrm{Hg}$, the diastolic, $60 \mathrm{~mm}$. The pulse rate was 96 beats per minute. The observations recorded in Table I were made and at the end of this time the patient's condition seemed unchanged. Two hundred cc. of a 25 per cent solution of albumin were given in $\mathbf{5 0}$ minutes. Following this, further studies were made. During the period of time from the beginning of the auricular catheterization to the completion of the second cardiac output, the patient received $200 \mathrm{cc}$. of normal saline by way of the catheter. The patient improved steadily while the albumin was administered and had no untoward reaction. His hands became warmer, the volume of the pulse increased, and he was less restless. His convalescence was uneventful.

Case 2. A 20-year-old Negress was admitted to the Grady Hospital soon after being stabbed in the posterior aspect of the right chest. The patient was slightly restless; the extremities were cool and somewhat moist. By auscultation, the arterial pressure was 80/60. Physical examination revealed evidence of fluid in the right chest. Preliminary observations were carried out, the results being shown in Table I. Following this, 50 grams of albumin in $200 \mathrm{cc}$. of fluid were given in 30 minutes. During the infusion, there were no untoward symptoms and the patient became more alert and cooperative. Observations made at this time showed the changes shown in Table $I$.

Case 3. A 30-year-old Negro came to the Grady Hospital Emergency Clinic a few minutes after being stabbed 
TABLE I

Summary of observations on Cases 1 and 2

\begin{tabular}{|c|c|c|c|c|}
\hline \multirow[t]{2}{*}{ - } & \multicolumn{2}{|c|}{$\begin{array}{l}\text { Case 1, Male, age } 45 \text { years. } \\
\text { Stabbed chest with hemothorax. } \\
\text { Surface area } 1.68 \text { 8q. meters }\end{array}$} & \multicolumn{2}{|c|}{$\begin{array}{l}\text { Case 2, Female, age } 20 \text { years. } \\
\text { Stabbed chest with hemothorax. } \\
\text { Surface area } 1.46 \text { sq. meters }\end{array}$} \\
\hline & $\underset{\text { observations }}{\text { Initial }}$ & $\begin{array}{l}\text { After } 50 \text { grams } \\
\text { of albumin }\end{array}$ & $\begin{array}{c}\text { Initial } \\
\text { observations }\end{array}$ & $\begin{array}{l}\text { After } 50 \text { grams } \\
\text { of albumin }\end{array}$ \\
\hline $\begin{array}{l}\text { Femoral aterial pressure (mm. } \mathrm{Hg} \text { ) } \\
\quad \text { systolic } \\
\quad \text { diastolic } \\
\text { mean } \\
\text { Auricular pressure (mm. water) } \\
\text { Pulse (beats per minute) } \\
\text { Hematocrit reading } \\
\text { Plasma protein (grams per } 100 \text { cc.) } \\
\text { Plasma volume (cc. per square meter) } \\
\text { Arterial oxygen content (volumes per } 100 \mathrm{cc} \text {.) } \\
\text { Mixed venous oxygen content (volumes per } 100 \mathrm{cc} \text {.) } \\
\text { A-V oxygen difference (volumes per } 100 \text { cc.) } \\
\text { Oxygen consumption (cc. per minute per sq. meter) } \\
\text { Cardiac output (liters per minute) } \\
\text { Cardiac index (liters per minute per sq. meter) }\end{array}$ & $\begin{array}{c}90 \\
56 \\
68 \\
15 \text { to } 20 \\
88 \\
36 \\
5.6 \\
1490 \\
14.5 \\
10.7 \\
3.8 \\
116 \\
5.1 \\
3.1\end{array}$ & $\begin{array}{c}110 \\
62 \\
81 \\
55 \text { to } 60 \\
100 \\
31 \\
5.6 \\
1850 \\
12.6 \\
10.0 \\
2.6\end{array}$ & $\begin{array}{c}80 \\
48 \\
62 \\
68 \\
26 \\
5.6 \\
1300 \\
9.4 \\
5.7 \\
3.7 \\
122 \\
4.8 \\
3.3\end{array}$ & $\begin{array}{c}96 \\
58 \\
71 \\
50 \\
75 \\
20 \\
5.5 \\
1850 \\
7.4 \\
4.2 \\
3.2 \\
123 \\
5.5 \\
3.8\end{array}$ \\
\hline
\end{tabular}

in the back with a knife. He had bled profusely and on arrival at the hospital the wound was spurting blood. The wound was in the left lower posterior chest and extended subcutaneously into the costovertebral angle, but there was no evidence of hemo- or pneumo-thorax. After closure of the laceration and stoppage of the bleeding, the patient was slightly dull mentally, his skin was moist and cool, the brachial arterial pressure was $150 / 68$ by the auscultatory method, and the pulse rate was 120 per minute.

A plasma volume determination was carried out, but readings were unsatisfactory because of lipemia. The hematocrit reading was $\mathbf{4 0}$ per cent. Hamilton manometer tracings taken from the femoral artery at this time showed a pressure of 148/84. The mean pressure was $105 \mathrm{~mm}$. of $\mathrm{Hg}$ and the pulse rate, 114. One hundred $\mathrm{cc}$. of a 25 percent solution of albumin were rapidly given, intravenously. There was no untoward reaction. Following the albumin solution, the hematocrit reading was 37 per cent. The arterial pressure stabilized at 160/94. The mean pressure was $115 \mathrm{~mm}$. of $\mathrm{Hg}$. The pulse rate was 96 beats per minute. The patient's mental state definitely improved. Over an hour later, $750 \propto c$. of physiological saline solution were given intravenously without change in the patient's condition.

Case 4. A 33-year-old Negro was admitted to the Emergency Clinic about 15 to 20 minutes after receiving a stab wound of the left thigh. It had bled profusely and on admission the patient was confused, his extremities were cold and moist, and the arterial pressure by the auscultatory method was $70 / 50 \mathrm{~mm}$. of $\mathrm{Hg}$.

The hematocrit reading was 38 per cent and plasma volume, approximately $2400 \mathrm{cc}$. (surface area 1.8 square meters). Hamilton manometer tracings at this time revealed a femoral pressure of $47 / 28$ and a mean pressure of $37 \mathrm{~mm}$. of $\mathrm{Hg}$. The pulse rate was 99 beats per minute. One hundred $c c$. of a 25 per cent solution of albumin were given intravenously. The arterial pressure increased to $88 / 52$, and the mean pressure rose to $61 \mathrm{~mm}$. of $\mathrm{Hg}$. The pulse rate was 114 beats per minute. There was no evidence of any untoward reaction. The hematocrit reading fell from the control level of 38 to 32 soon after the albumin infusion was completed, later falling to 30 . This represented an increase in plasma volume of $800 \mathrm{cc}$. One and one-half hours later, $500 \mathrm{cc}$. of normal saline solution were given intravenously. The hematocrit reading after the infusion was 29 and the arterial pressure had not changed. The patient's temperature remained normal.

Case 5. A 30-year-old Negro male was stabbed in the left temporal region, apparently involving the major temporal vessels. Despite the severe bleeding, it was almost an hour before he reached the hospital. On arrival; he was still bleeding considerably. His blood pressure at this time by the auscultatory method was $90 / 60$, but in general, his condition seemed to be good. Considerable difficulty was encountered in controlling the severed temporal vessels, which had retracted. After about an hour, he attempted to sit up in the Emergency Clinic, but collapsed. It was then noted that his pulse was weaker and more rapid. He failed to improve by further rest in the Trendelenburg position. Blood volume determination about $3 \frac{1}{2}$ hours after injury revealed a plasma volume of $3200 \mathrm{cc}$. (surface area of 2 square meters), and a hematocrit reading of 40 . The femoral arterial pressure at this time was 86/54. The mean femoral pressure was $68 \mathrm{~mm}$. of Hg. About $4 \frac{1}{2}$ hours after injury, $200 \mathrm{cc}$. of a 25 per cent albumin solution were given intravenously, in approximately 35 minutes. The femoral arterial pressure rose to $106 / 60$ after the albumin. The mean pressure was $79 \mathrm{~mm}$. of $\mathrm{Hg}$. The patient stated that he felt much better and his level of awareness appeared to rise. There was no evidence of any untoward reaction. The oral temperatures before and after were normal. The hematocrit 
TABLE II

Summary of observations on Case 6

Female, age 58. Severe second and third degree burns, previous hypertension (surface area 1.6 sq. meters)

\begin{tabular}{|c|c|c|c|c|}
\hline & $\begin{array}{l}\text { Initial observa- - } \\
\text { tions at } 12: 36 \text { a.m. } \\
1,000 \text { cc. plasma } \\
\text { already received }\end{array}$ & $\begin{array}{c}\text { Obeervations at } \\
\text { 2:17 a.m. after } \\
500 \text { cc. of } \\
\text { phyriological } \\
\text { saline eolution }\end{array}$ & $\begin{array}{c}\text { Obeervations at } \\
7: 37 \text { a.m. after } \\
3,000 \text { cc. of } \\
\text { saline and } \\
\text { glucose solutions }\end{array}$ & $\begin{array}{c}\text { Obeervations at } \\
\text { 9:25 a.m. after } \\
50 \text { grams of } \\
\text { albumin }\end{array}$ \\
\hline $\begin{array}{l}\text { Femoral arterial pressure (mm. } \mathrm{Hg} \text { ) } \\
\quad \text { systolic } \\
\text { diastolic } \\
\text { mean } \\
\text { Auricular pressure (mm. water) } \\
\text { Pulse (beats per minute) } \\
\text { Hematocrit reading } \\
\text { Plasma protein (grams per } 100 \text { cc.) } \\
\text { Arterial oxygen content (volumes per } 100 \text { cc.) } \\
\text { Mixed venous oxygen content (oolumes per } 100 \text { cc.) } \\
\text { A-V oxygen difference (volumes per } 100 \text { cc.) } \\
\text { Oxygen consumption (cc. per minute per sq. meter) } \\
\text { Cardiac output (liters per minute) } \\
\text { Cardiac index (liters per minute per sq. meter) }\end{array}$ & $\begin{array}{c}128 \text { to } 190^{*} \\
80 \text { to } 100 \\
117 \\
15 \text { to } 20 \\
115 \\
39 \\
6.4 \\
16.1 \\
10.9 \\
5.2 \\
141 \\
4.3 \\
2.7\end{array}$ & $\begin{array}{c}128 \text { to } 168^{*} \\
76 \text { to } 92 \\
98 \\
5 \text { to } 10 \\
94 \\
38 \\
5.9 \\
15.7 \\
9.8 \\
5.9 \\
113 \\
3.0 \\
1.9\end{array}$ & $\begin{array}{c}118 \text { to } 150^{\circ} \\
78 \text { to } 88 \\
95 \\
5 \text { to } 10 \\
136 \\
39 \\
5.9 \\
15.6 \\
10.5 \\
5.1 \\
112 \\
3.5 \\
2.2\end{array}$ & $\begin{array}{c}156 \text { to } 204^{*} \\
86 \text { to } 106 \\
126 \\
50 \text { to } 55 \\
136 \\
33 \\
5.5 \\
13.2 \\
8.9 \\
4.3 \\
160 \\
5.9 \\
3.7\end{array}$ \\
\hline
\end{tabular}

- Maximum and minimum respiratory variations.

reading fell to 34 per cent, representing a $900 \mathrm{cc}$. increase in plasma volume.

Case 6. A 58-year-old Negress was admitted to the hospital soon after receiving a severe burn. Seven years previously she had suffered from a hemiplegia and there was a history of high blood pressure. On the night of admission, her dress had become ignited, and on entry to the hospital, it was estimated that about 60 to 70 per cent of the body surface was involved in second and third degree burns. Because of the extent of the involvement, auscultatory blood pressure readings were not obtained on admission, and the peripheral pulses were not palpable. The burns were immediately treated with boric acid ointment dressing and pressure bandages on the extremities. During this time, she received $1000 \mathrm{cc}$. of plasma. Following this, circulatory studies were carried out and the results are tabulated in Table II. There was a very marked respiratory variation in the arterial pressure, the values recorded being the maximum and minimum values. Because of considerable hemoglobinemia, blood volume determinations were unsatisfactory. Physiological saline solution was allowed to drip through the catheter at the rate of $200 \mathrm{cc}$. per hour. Almost 2 hours later, another set of determinations was carried out. Following this, $1500 \propto c$. of 5 per cent glucose in distilled $\mathrm{H}_{2} \mathrm{O}$ were given in addition to the saline solution dripping through the catheter, and further circulatory measurements were made. Later, $200 \mathrm{cc}$. of 25 per cent albumin solution were given in 45 minutes. There was no evidence of toxic reaction and, as shown by the data recorded in Table II, the circulation improved greatly. No further therapy was given at this time and the patient's condition remained good, requiring no further plasma for almost 10 hours.

\section{DISCUSSION}

The concentrated albumin solutions were easy to administer and caused no unfavorable reactions in this group of patients. In each instance, the patient showed signs of clinical improvement, and where measurements were made, this improvement could be charted quantitatively. In each of the 6 patients, the femoral arterial pressure showed a significant rise. The hematocrit reading uniformly decreased without a corresponding decrease in the protein concentration. In 4 instances, plasma volume determinations were made before treatment. Calculating the increase in the plasma volume from the initial determination and the hematocrit reading before and after receiving the albumin, the plasma volume increased 600,800 , and $900 \mathrm{cc}$. in the patients receiving 50 grams of albumin. The average increase in volume was $16 \mathrm{cc}$. for each gram of albumin. This compares closely with observed data of Heyl, Gibson, and Janeway (9), who report that 1 gram of albumin produced an average increase in volume of $17.4 \mathrm{cc}$. and of Scatchard, Batchelder, and Brown (10), who find $18 \mathrm{cc}$. per gram by in vitro measurements of osmotic pressure. These 3 patients received sufficient albumin to restore the arterial pressure to approximately the normal level. Case 4 was 
given only 25 grams of albumin and this was insufficient to raise the arterial pressure to the normal level. One hour after the administration of albumin was completed, the increase in plasma volume measured $800 \mathrm{cc}$. It is felt that the large increase in plasma volume in this patient was caused in part by the albumin, but in part represented the usual hemodilution by extracellular fluid which occurs when insufficient protein is given to restore the plasma volume to normal.

In the 2 cases in which it was measured, the auricular pressure rose as the plasma volume increased. The difference between the oxygen content of the mixed venous blood and the arterial blood decreased as the circulation improved, and in the 2 cases in which the determination was made, the cardiac output increased. This was particularly striking in Case 6, in whom 3 cardiac output determinations were made before the albumin was given. After the administration of 50 grams of albumin, the cardiac output had increased from 3.5 to 6.4 liters per minute.

\section{SUMMARY AND CONCLUSIONS}

A concentrated solution of human serum albumin was given to 6 patients with circulatory failure associated with a decrease in blood volume. In each case, there was distinct clinical improvement without evidence of any undesirable side effects. The increase in plasma volume was commensurate with the predicted osmotic effect of the albumin. Determinations of the arterial pressure, the auricular pressure, and the cardiac output, all revealed the beneficial effects of the albumin.

This work was carried out with the technical assistance of Miss Maurine Giese, Miss Eloise Cavin, and Mrs. Janet Stegeman.

\section{BIBLIOGRAPHY}

1. Cohn, E. J., Oncley, J. L., Strong, L. E., Hughes, W. L., Jr., and Armstrong, S. H., Jr., Chemical, clinical, and immunological studies on the products of human plasma fractionation. I. The characterization of the protein fractions of human plasma. J. Clin. Invest., 1944, 23, 417.

2. Janeway, C. A., Gibson, S. T., Woodruff, L. M., Heyl, J. T., Bailey, O. T., and Newhouser, L. R., Chemical, clinical, and immunological studies on the products of human plasma fractionation. VII. Concentrated human serum albumin. J. Clin. Invest., 1944, 23, 465.

3. Cournand, A., Riley, R. L., Bradley, S. E., Breed, E. S., Noble, R. P., Lauson, H. D., Gregersen, M. I., and Richards, D. W., Studies of the circulation in clinical shock. Surgery, 1943, 13, 964.

4. Hamilton, W.F., Brewer, G., and Brotman, I., Pressure pulse contours in the intact animal. I. Analytical description of a new high-frequency hypodermic manometer with illustrative curves of simultaneous arterial and intracardiac pressures. Am. J. Physiol., 1934, 107, 427.

5. Cournand, A., and Ranges, H. A., Catheterization of the right auricle in man. Proc. Soc. Exper. Biol. and Med., 1941, 46, 462.

6. Peters, J. P., and Van Slyke, D. D., Quantitative clinical chemistry. Volume II. Methods. Williams and Wilkins Company, Baltimore, 1932.

7. Gregersen, M. I., Gibson, J. J., and Stead, E. A., Jr., Plasma volume determination with dyes: errors in colorimetry; use of the blue dye T-1824. Am. J. Physiol., 1935, 113, 54.

8. Barbour, H. G., and Hamilton, W. F., Blood specific gravity: its significance and a new method for its determination. Am. J. Physiol., 1924, 69, 654.

9. Heyl, J. T., Gibson, J. G., 2nd, and Janeway, C. A., Studies on the plasma proteins. V. The effect of concentrated solutions of human and bovine serum albumin on blood volume after acute blood loss in man. J. Clin. Invest., 1943, 22, 763.

10. Scatchard, G., Batchelder, A. C., and Brown, A., Chemical, clinical, and immunological studies on the products of human plasma fractionation. VI. The osmotic pressure of plasma and of human serum albumin. J. Clin. Invest., 1944, 23, 458. 